Brit. F. vener. Dis. (1967), 43, 111.

\title{
THE RAPID DETECTION OF METRONIDAZOLE IN URINE*
}

\author{
BY \\ P. DUREL, J. COUTURE, AND M. T. BASSOULLET \\ Institut Alfred Fournier, Paris
}

When metronidazole (Flagyl) is prescribed for trichomoniasis or lambliasis, it is unusual for the treatment not to be followed-up; however, it is possible that the patient does not take the drug, and the doctor may wonder whether the drug is being properly absorbed.

It is also thought that metronidazole decreases the desire for alcohol in alcoholics. Here the co-operation of the patient may be doubtful and the question of whether or not he is taking the drug arises much more often. It appears, therefore, that it would be of value to establish whether metronidazole has been ingested and if it has been absorbed.

A well-equipped laboratory can easily study the presence of metronidazole in blood or in urine but this cannot be carried out in an ordinary clinic. In the absence of a rapid blood test, the simple and quick detection of metronidazole in urine is of practical interest.

A similar problem arose 20 years ago concerning sulphonamides and prostitutes. We had to examine prostitutes periodically for gonorrhoea, and quite often before this weekly examination, they took sulphonamides in order to "have a good specimen". Of course, they emphatically denied this when asked.

We noted, at this time, a paper by Vanhaecke (1944) which stated that a yellow colouration was produced when newspaper, previously acidified, was dipped into the urine of patients taking sulphonamides. There was diazotization between certain components of the paper and the $\mathrm{NH}_{2}$ group of the sulphonamide. We often used this method with known prostitutes and were able to convince them that they were trying to deceive us.

Our colleague, Dubost (1944) showed that the principal reactive component in the paper was furfurol, or lignin, and that a similar reaction could

\footnotetext{
* Received for publication July 18, 1966.
}

be obtained with blotting paper impregnated with a solution of $p$-dimethylaminobenzaldehyde or of vanilline. It was therefore thought that, because of the $\mathrm{NO}_{2}$ group in metronidazole, a similar reaction would occur after reduction of the nitro group.

After reduction by zinc in an acid medium, the two aromatic aldehydes were then tried. Only p-dimethylaminobenzaldehyde gave a salmon-pink colouration varying in intensity with the amount of metronidazole present in the specimen.

Our idea was to give venereologists with limited laboratory facilities an easy method for detecting metronidazole in urine by preparing disks impregnated with dimethylaminobenzaldehyde. Better equipped laboratories could use a variation of our technique employing Ehrlich's reagent in a test tube as done by McFadzean (1966).

\section{Reagents}

\section{Method}

(a) 30 per cent. citric acid solution.

(b) Pure zinc (pastilles).

(c) Courtonne's reagent (30 per cent. neutral solution of lead acetate).

(d) Reagent disks.

Cellulose disks as used for antibiotics assays are impregnated with a solution of $p$-dimethylaminobenzaldehyde bisulphite. After air-drying on a grill the reagent disks will keep for at least 6 months in an airtight tin.

(e) $p$-dimethylaminobenzaldehyde bisulphite solution.

Dissolve $750 \mathrm{mg}$. aldehyde in $3 \mathrm{ml} .95$ per cent. alcohol at $40-50^{\circ} \mathrm{C}$. Add $2.5 \mathrm{ml}$. sodium bisulphite solution (density 1.32: 23 per cent. $\mathrm{SO}_{2}$ to iodine), then 4-5 ml. water. A precipitate is obtained which dissolves at $40-50^{\circ} \mathrm{C}$. and is re-precipitated on cooling. A stable solution is obtained by the addition of $2 \mathrm{ml}$. $\mathrm{N} \mathrm{HCl}$, and the whole is made up to $100 \mathrm{ml}$. with distilled water. The disks are impregnated with this solution. 


\section{Comments}

(a) Reduced normal urine gives a lemon-yellow colour with the disks which increases in intensity with the concentration of urine; with highly concentrated urine this can mask the salmon-pink colour due to metronidazole.

(b) The clarification of the urine by Courtonne's reagent eliminates most of the components giving the yellow colour without reducing the amount of metronidazole present.

(c) The reduction of urine by zinc must be very brisk. The zinc must be pure and not carbonated. After several experiments, we found that zinc in the form of pastilles was the most appropriate to use and it is also convenient to decarbonate. It should be cleaned before use in hot or cold $2 \mathrm{~N} \mathrm{H}_{2} \mathrm{SO}_{4}$ for about 5 minutes depending on the degree of carbonation of the sample, followed by rapid and thorough rinsing in distilled water.

(d) With urines of density of 1001 to 1012 , concentrations of metronidazole of at least $50 \mu \mathrm{g} . / \mathrm{ml}$. can be easily detected, giving a pinkish-ochre colour varying in intensity with the concentration of metronidazole. More concentrated urines have to be diluted by equal parts with distilled water.

\section{Technique}

(a) To $10 \mathrm{ml}$. urine of suitable density in a test tube add $2 \mathrm{ml} .30$ per cent. citric acid solution, then excess zinc, in order to give a very rapid reduction.

(b) Place the test tube holder in a boiling water bath for 4 minutes.

(c) Cool rapidly under running water.

(d) Add $1.5 \mathrm{ml}$. Courtonne's reagent, shake, and filter after 5 minutes.

(e) Put 2 drops of the filtrate on a reagent disk.

(f) At the same time put 2 drops of the patient's unreduced urine on another disk to act as a control. It would seem logical to use as a control a reduced urine of similar density but without metronidazole. Experience has shown that for a small quantity such as $\mathbf{2}$ drops, the lemon-yellow colour produced by the reduction of normal urine is negligible. One can therefore use as control an unreduced urine-for simplicity-that of the patient.

(g) Allow the two disks to dry at room temperature. If metronidazole is present in the urine in large quantities the salmon-pink is noticeable after 15 minutes. If the urine has a normal concentration of metronidazole the colour appears in $\mathbf{3 0}$ minutes. The reading is taken at $\mathbf{3 0}$ minutes.

\section{Results}

The salmon-pink colour-which intensifies during drying-is easily distinguishable from the lemonyellow colour given by normal reduced urine containing no metronidazole.

It is easy to detect $50 \mu \mathrm{g} . / \mathrm{ml}$, the normal minimum content in urine if the dose is $250 \mathrm{mg}$. morning and evening or $200 \mathrm{mg}$. 3 times a day. One can determine by this method whether the prescription has been followed (the limit of sensitivity is $20 \mu \mathrm{g}$. $/ \mathrm{ml}$.)

The intensity of colouration is sufficiently proportional to the concentration of the drug in the urine to enable the results to be, to a certain extent, quantitative (Fig. 1, opposite).

\section{Discussion}

The suggested method is simple and only requires disks prepared in advance, zinc, citric acid, and lead acetate solutions and can be used in the smallest laboratory or clinic.

The result is obtained in about an hour, and it is not usually necessary to make the patient wait as the information is only important for the doctor.

Our method can be varied. McFadzean (1966) suggested that laboratories could use Ehrlich's reagent in a test tube.

We have used either the Ehrlich's reagent which is used in France to detect urobilinogen in the urine (Grimbert's formula):

2 per cent. solution of $p$-dimethylaminobenzaldehyde in alcohol: 1 volume

Pure $\mathrm{HCl}$ : .. 1 volume

or the Ehrlich's reagent which is used to detect urobilinogen in the urine and in the faeces (Sparkman's formula):

$$
\begin{aligned}
& p \text {-dimethylaminobenzaldehyde: } 10 \mathrm{~g} \text {. }
\end{aligned}
$$

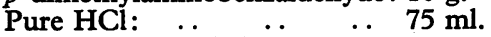

$$
\begin{aligned}
& \text { Dissolve and shake } \\
& \text { Distilled water .. .. to } 150 \mathrm{ml} \text {. }
\end{aligned}
$$

To $5 \mathrm{ml}$. of the above-mentioned filtrate in a test tube we added $0.5 \mathrm{ml}$. Ehrlich's reagent. The salmon-pink colour produced was compared with the normal reduced urine (without metronidazole). This technique allows a quantitative approximation (Fig. 2, opposite) using a range containing known quantities of metronidazole.

Sparkman's formula has given better differentiations for weak concentrations than Grimbert's formula.

One can accelerate these reactions by putting the tubes for a few seconds in a boiling water bath; the reading can then be made after 5 to 6 minutes. Thus, for laboratories with Ehrlich's reagent available, the modification suggested by McFadzean is simpler, more sensitive, and especially quicker than our original technique.

\section{Summary}

It may be desirable to know if a patient has been taking metronidazole as prescribed or if it is being properly absorbed. The detection of the compound in blood or in urine is easy in well-equipped laboratories, but the authors, stimulated by a 


\section{DETECTION OF METRONIDAZOLE IN URINE}

Témoin

Urine nornale Urine additionníe de playyl à la dose de : $\overbrace{\text { vidivite }}^{\mathrm{d}=1} \underbrace{011}_{\text {réduik }}$

)(

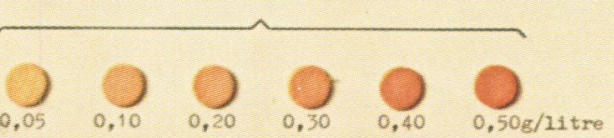

Urines de aujeta ayent abaorbe, $2 \mathrm{~h}$ ou $4 \mathrm{~h}$ avant, $250 \mathrm{mg}$ et $1000 \mathrm{mg}$ de Flagyl
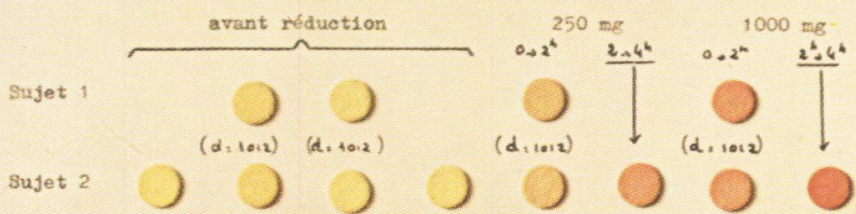

$(d=1009)(d=1018)(d=1010)(d=100 p)(d, 100 y)(d=1013)(d=10+0)(d+100 y)$

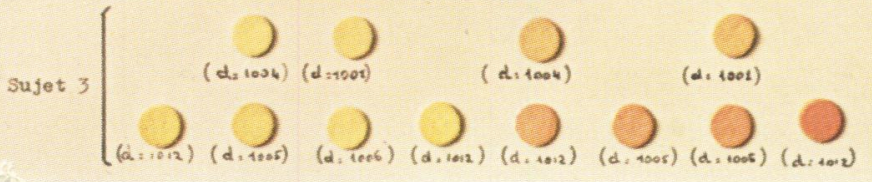

FIG. 1.-Disk technique for the detection of metronidazole in urine.
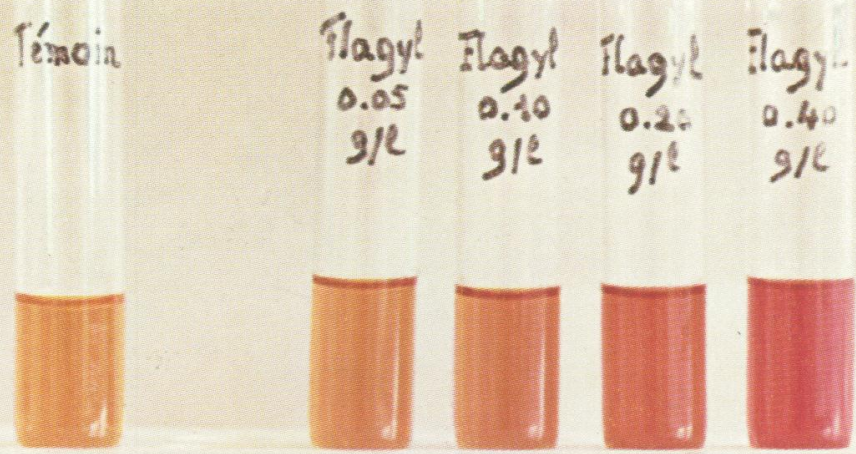

FIG. 2.-Tube technique for the detection of metronidazole in urine. 
publication by Vanhaecke on the sulphonamides, have described a simple and relatively quick method which can be used in less well-equipped laboratories.

Disks impregnated with $p$-dimethylaminobenzaldehyde are prepared in advance. The urine is acidified, reduced with nascent $\mathrm{H}_{2}$, and subsequently cleared with a solution of lead acetate and filtered. After applying the filtrate to the disks and drying, a salmon-pink colouration is obtained, the intensity of which is proportional to the quantity of metronidazole in the urine. The urinary concentrations obtained with standard dose régimes are easily detected.

When Ehrlich's reagent is available, the reaction can be undertaken in a test tube which gives a more rapid reading.

\section{REFERENCES}

Dubost, P. (1944). Personal communication.

McFadzean, J. A. (1966). Personal communication.

Vanhaecke, M. E. (1944). Echo méd. Nord, $3^{e}$ sér, 15, 236.
Détection rapide du métronidazole dans l'urine

\section{Résumé}

La question peut sé poser de savoir si un malade a bien ingéré le métronidazole prescrit ou si son organisme l'a bien assimilé. La détection du produit dans le sang ou l'urine est facile dans des laboratoires bien équipés, mais les auteurs, s'inspirant d'une publication de Vanhaecke pour les sulfamides, décrivent une méthode simple et relativement rapide qui peut être mis en cuvre dans des laboratoires beaucoup moins bien équipés.

On prépare à l'avance des disques imprégnés de $p$. diméthylaminobenzaldéhyde. On défèque par l'acétate de plomb l'urine acidifiée. On la réduit par l'hydrogène naissant et l'on obtient après dessication, une coloration rose-saumon dont l'intensité est proportionnelle à la teneur en métronidazole. Les concentrations urinaires telles qu'on peut les trouver avec les posologies habituelles sont facilement mises en évidence.

Lorsque l'on dispose d'un réactif d'Ehrlich, la réaction peut être pratiquée en tube, ce qui donne une réponse plus rapide. 